\title{
Adsorption of Herbicide Butachlor in Cultivated Soils of Golestan Province, Iran
}

\author{
Sahar Armanpour1, Liang Bing ${ }^{2}$ \\ ${ }^{1}$ College of Mining, Liaoning Technical University, Fuxin, China \\ ${ }^{2}$ Department of Mechanics and Engineering Sciences, Liaoning Technical University, Fuxin, China \\ Email: sahar.armanpour@gmail.com
}

Received 1 April 2015; accepted 18 April 2015; published 23 April 2015

Copyright (C) 2015 by authors and Scientific Research Publishing Inc.

This work is licensed under the Creative Commons Attribution International License (CC BY).

http://creativecommons.org/licenses/by/4.0/

(c) () D Open Access

\begin{abstract}
Butachlor is a non-ionic herbicide that has been applied widely for agriculture, especially in paddy fields. Through batch equilibration experiments, the adsorption characteristics of butachlor were investigated in eight cultivated soil samples collected from Golestan Province, Iran. The data obtained from adsorption equilibrium experiments fitted the linear equation very well. Results showed that butachlor had weak to moderate adsorption capability in different soils. Trend of butachlor adsorption was similar to the order of abundance of organic carbon in the soils. The Gibbs free energy values were found negative and adsorption was spontaneous and exothermic in nature. Statistical analysis showed that organic carbon, CEC (cation exchange capacity), and the Rt ratio (ratio of TNV to organic matter content) were the more effective parameters governing butachlor retention and mobility in soils.
\end{abstract}

\section{Keywords}

Butachlor, Soil, Organic Matter, Clay, Adsorption, Mobility

\section{Introduction}

Among the different groups of pesticides, herbicides are more likely to pollute soils. The sorption properties of the herbicides are very important, especially as the first herbicide applications are necessary at the early growth stages, when crop interception is minimal, and therefore, the major part of the applied dose actually reaches the soil [1]. Herbicides are especially likely to cause environmental problems as they are used in large quantities and are persistent in the paddy field and the environment [2]. Herbicides could reach surface and groundwater by runoff and leaching. These movements are attenuated by natural processes such as adsorption on soil constituents, as well as chemical and biological degradation [3]. Butachlor (N-(butoxymethyl)-2-chloro-N-(2, 6-diethyl- 
phenyl) acetamide) is a selective systemic herbicide, mainly used to pre-emergent control of annual grass with application rate 3000 - $4000\left(\mathrm{~g} \cdot \mathrm{ha}^{-1}\right)$. Butachlor has widely been used in the northern provinces of Iran such as Golestan Province, mostly in paddy fields. As rice fields are mainly located alongside rivers in north of Iran, this herbicide is often released into rivers and can affect its inhabitants. While butachlor is in common use in Iran and has been detected in surface and ground waters, it is expired and unallowable in the EU because of its toxicity and environmental impacts. Its environmental impact has been investigated widely, and the investigations show that butachlor has toxicity to aquatic organisms [4]. Especially, it has genotoxicity to the amphibian animals [5].

Up to now, many studies on the sorption of butachlor by soil revealed that only soil organic matter was closely related to sorption capability [6] [7], and little evidence indicated whether other soil characteristics such as inorganic components and CEC would influence the adsorption of butachlor by soil [8]. As adsorption of butachlor has not been studied on Iranian soils, its knowledge is necessary for predicting mobility of butachlor in soil environments. This study can help to better understand effects of soil properties on mobility of butachlor in representative soils of most common soils of Golestan Province.

\section{Materials and Methods}

\subsection{Materials}

Eight soil samples collected from the surface horizon $(0-20 \mathrm{~cm})$ in agricultural fields of Golestan Province (Figure 1). The selection of samples was based on existing maps to give a gradient in $\mathrm{pH}, \mathrm{EC}, \mathrm{CEC}$ and to have a range in texture and organic carbon content. The soil samples were air-dried and sieved through a $2 \mathrm{~mm}$ mesh sieve to remove debris and large particles. Then soil samples were analyzed for the physiochemical properties including $\mathrm{pH}, \mathrm{EC}$ electrical conductivity, CEC, organic carbon content (OC), clay $(<2 \mu \mathrm{m})$, silt $(2-50 \mu \mathrm{m})$ and sand $(50-2000 \mu \mathrm{m})$ and TNV (total neutralizing value). Mineralogical composition of the soils was determined by X-Ray Diffraction analysis (XRD). Some physicochemical properties and mineralogical composition of soils are shown in Table 1. Analytical grade butachlor with a purity of $97 \%$ was purchased from Shenyang Research Institute of Chemical Industry, China. Other chemical reagents and solvents used were of HPLC grade. The molecular structure and physicochemical properties of butachlor [9] are given in Table 2.

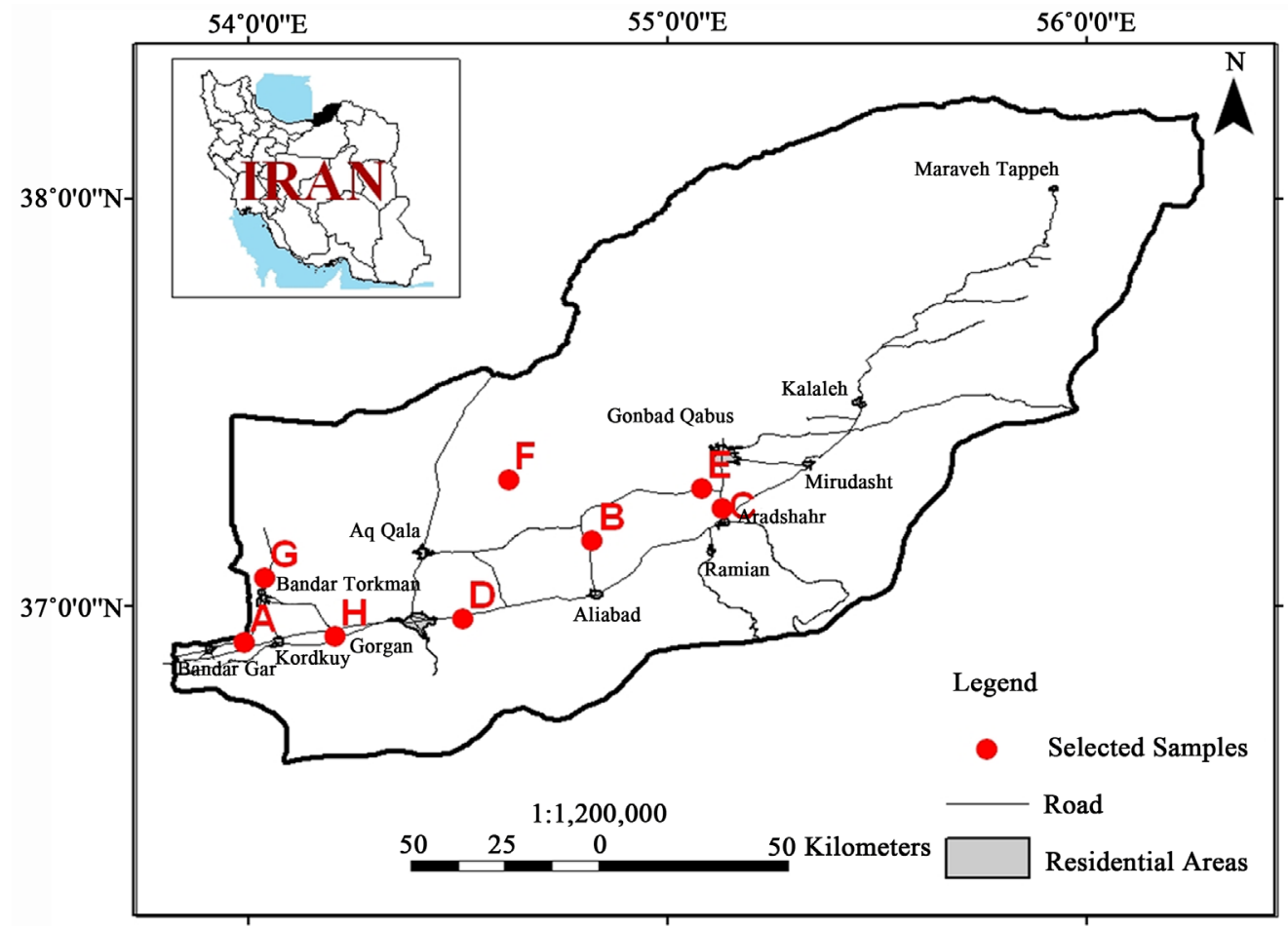

Figure 1. Sampling sites in Golestan Province, North of Iran. 
Table 1. Some physicochemical properties and mineralogical composition of studied soils.

\begin{tabular}{|c|c|c|c|c|c|c|c|c|c|c|c|c|}
\hline Sample & Sand & Silt & Clay & $\mathrm{OC}$ & $\mathrm{OM}$ & $\mathrm{TNV}$ & $\mathrm{EC}$ & CEC & \multirow{2}{*}{$\mathrm{pH}$} & \multirow{2}{*}{$\mathrm{RCO}$} & \multirow{2}{*}{ Rt } & \multirow{2}{*}{ Mineralogy } \\
\hline Unit & \multicolumn{6}{|c|}{$(\%)$} & $(\mathrm{ds} / \mathrm{m})$ & $(\mathrm{meq} / 100 \mathrm{~g})$ & & & & \\
\hline A & 15 & 53 & 32 & 2.30 & 3.97 & 13.11 & 0.85 & 31.3 & 7.07 & 13.9 & 3.3 & $\mathrm{Q}, \mathrm{Cl}, \mathrm{I}>\mathrm{F}, \mathrm{Ca}$ \\
\hline B & 29 & 35 & 36 & 1.99 & 3.43 & 19.31 & 3.05 & 27.93 & 7.1 & 18.07 & 5.62 & $\mathrm{Q}, \mathrm{Ca}>\mathrm{K}, \mathrm{M}>\mathrm{D}$ \\
\hline $\mathrm{C}$ & 28 & 42 & 30 & 2.38 & 4.1 & 12.23 & 1.4 & 30.5 & 7.27 & 12.61 & 2.98 & $\mathrm{Q}>\mathrm{Cl}, \mathrm{Ca}, \mathrm{I}$ \\
\hline $\mathrm{D}$ & 29 & 37 & 34 & 1.37 & 2.36 & 29.68 & 1.35 & 23.03 & 7.33 & 24.82 & 12.57 & $\mathrm{Q}, \mathrm{Ca}>\mathrm{D}, \mathrm{I}, \mathrm{Di}$ \\
\hline $\mathrm{E}$ & 17 & 47 & 36 & 2.66 & 4.59 & 14.41 & 1.05 & 35 & 7.22 & 13.51 & 3.14 & $\mathrm{Q}>\mathrm{Ca}, \mathrm{K}, \mathrm{I}>\mathrm{Mo}$ \\
\hline $\mathrm{F}$ & 19 & 49 & 32 & 1.33 & 2.3 & 23.74 & 3.18 & 18 & 7.23 & 24.02 & 10.34 & $\mathrm{Q}, \mathrm{Ca}, \mathrm{F}>\mathrm{K}, \mathrm{M}$ \\
\hline G & 28 & 56 & 16 & 0.59 & 1.02 & 22.55 & 71.3 & 5 & 8.1 & 27.12 & 22.17 & $\mathrm{Q}, \mathrm{Ca}, \mathrm{G}>\mathrm{I}>\mathrm{H}$ \\
\hline $\mathrm{H}$ & 38 & 46 & 16 & 0.87 & 1.51 & 24.01 & 0.8 & 9.24 & 6.85 & 18.29 & 15.92 & $\mathrm{Q}, \mathrm{Ca}>\mathrm{K}, \mathrm{I}>\mathrm{D}$ \\
\hline
\end{tabular}

$\mathrm{OM}$ : organic matter $(\% \mathrm{OM}=1.724 \% \mathrm{OC})$. RCO: the ratio of clay content to total organic carbon content $(\mathrm{RCO}=\%$ clay $/ \% \mathrm{OC})$. Rt: the ratio of calcite (here TNV) content to organic matter content ( $\left.\mathrm{Rt}=\% \mathrm{CaCO}_{3} / \% \mathrm{OM}\right)$. Mineralogy: clay minerals (K, kaolinite; $\mathrm{Cl}$, Clinochlore; I, Illite; Mo, Montmorillonite; Di, Dickite), silicate minerals (Q, quartz; F, felspar; M, mica), carbonate minerals (Ca, Calcite; D, Dolomite), oxide minerals (H, Hematite), sulfate minerals (G, Gypsum).

Table 2. Molecular structure and physicochemical properties of butachlor.

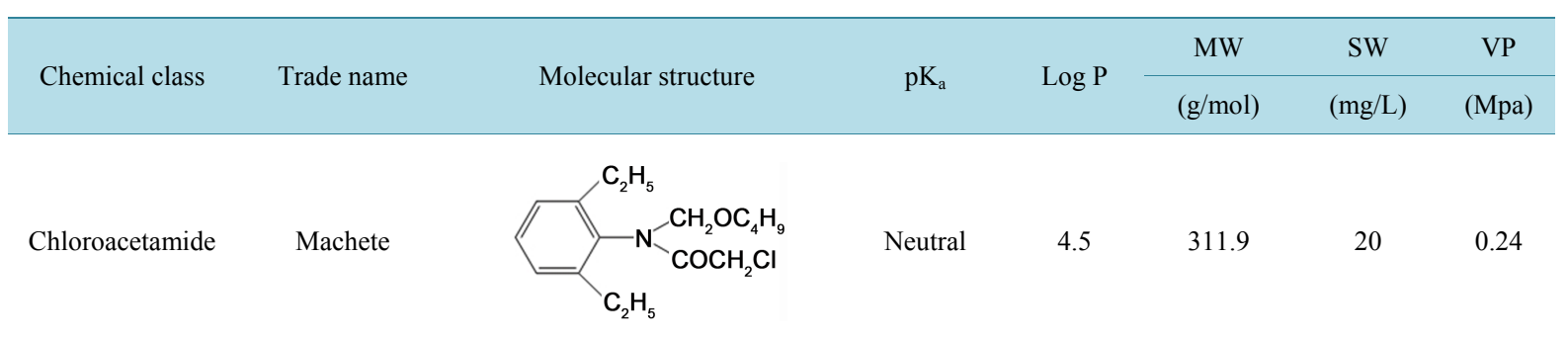

\subsection{Methods}

All adsorption experiments were carried out in duplicate by using a standard batch equilibrium method [10]. To minimize the variation of ionic strength, $0.01 \mathrm{M} \mathrm{CaCl}_{2}$ solution was used as a background electrolyte. The stock solution of butachlor was prepared in methanol, and then was diluted by $0.01 \mathrm{M} \mathrm{CaCl}_{2}$ solution to obtain the working standard solution. Concentration dilution series was prepared to check the linearity of detection and construction of the HPLC calibration curves. Soil to solution ratio of 1:5 (w:w) was chosen according to the preliminary experiments. Adsorption kinetic experiments were carried out to determine equilibration time. Samples of 5 grams soil were added to conical flasks containing $23 \mathrm{~mL} 0.01 \mathrm{M} \mathrm{CaCl}_{2}$ solution. All samples were pre-equilibrated ( $12 \mathrm{~h}$ ) overnight. The final volume of $25 \mathrm{~mL}$ aqueous phase was obtained by addition of butachlor stock solution in order to obtain the desire final concentrations. Then, all the suspensions were shaken on a rotary shaker at $150 \mathrm{rpm}$ for a period of $48 \mathrm{~h}$ at $27^{\circ} \mathrm{C} \pm 1^{\circ} \mathrm{C}$. From flasks, $5 \mathrm{~mL}$ of supernatant was collected at time intervals of $0.25,0.5,1,2,3,6,9,24,48 \mathrm{~h}$ and were centrifuged at $4000 \mathrm{rpm}$ for $15 \mathrm{~min}$, and then supernatant analyzed by HPLC, to measure $\mathrm{C}_{\mathrm{e}}$, the concentration of pesticide remaining in supernatant $(\mathrm{mg} / \mathrm{L})$, using the calibration curve regression equation. Duplicates without soil were used as references for $\mathrm{C}_{\mathrm{i}}$, the initial concentration $(\mathrm{mg} / \mathrm{L})$. Adsorption equilibrium experiments were conducted at the ratio of soil per solution (1:5) and initial concentrations of $1,5,10,15,20,25,50 \mathrm{mg} / \mathrm{L}$. The reaction mixtures were agitated in a rotary shaker as previously noted, until the equilibrium was established. Conical flasks without soil were also served as control sample to evaluate the effect of butachlor adsorption on the conical flasks glassware and the following possible degradation during the process. After $24 \mathrm{~h}$ (estimated equilibration time), $5 \mathrm{~mL}$ of supernatant was collected, next centrifuged and analysis with HPLC similarly as before. Chromatographic analysis was performed with a SHIMADZU liquid chromatograph (SHIMADZU, Kyoto, Japan), system equipped with a UV-SPD-20AV detector. The column was Symmetry C18 (250 mm length, $4.6 \mathrm{~mm}$ i.d., $5 \mu \mathrm{m}$ particle size). The absorbance wave- 
length was $215 \mathrm{~nm}$. The mobile phase was methanol: distilled water $(75: 25, \mathrm{v} / \mathrm{v})$ with flow rate of $1 \mathrm{~mL} / \mathrm{min}$ and the injection volume was $10 \mu \mathrm{L}$. The total run time was $10.0 \mathrm{~min}$. The retention time of butachlor was $5.5 \mathrm{~min}$.

\section{Result and Discussion}

\subsection{Soil Characterization}

The soil samples belong to different textural classes: silty clay loam ((a), (e) and (f)), clay loam ((b), (c) and (d)), silt loam (g) and loam (h). Soils showed organic matter content varied from $1.02 \%$ to $4.59 \%$. The clay content ranges between $16 \%$ and $36 \%$ whereas insignificant variation of $\mathrm{pH}$ was observed. There are positive correlation between clay and OC $(\mathrm{r}=0.77, p \leq 0.05)$ as well as between clay and CEC content $(\mathrm{r}=0.87, p \leq 0.01)$. Dominant clay minerals are illite and kaolinite and quartz and calcite are present in all samples.

\subsection{Adsorption Kinetic Study}

Kinetic experiments were conducted with initial concentrations of 1,25 and $50 \mathrm{mg} / \mathrm{L}$, to determine contact time required for adsorption equilibrium attained and $24 \mathrm{~h}$ was selected as the desired equilibrium time (Figure 2). The adsorption kinetic curves exhibited two distinct stages, a rapid adsorption in the initial stage (within $5 \mathrm{~h}$ ) followed by a slow adsorption. This phenomenon was due to the fact that a large number of vacant surface sites were available for adsorption during the initial stage, then the remaining vacant surface sites were difficult to be occupied due to repulsive forces between the solute molecules on the solid and bulk phases [11].
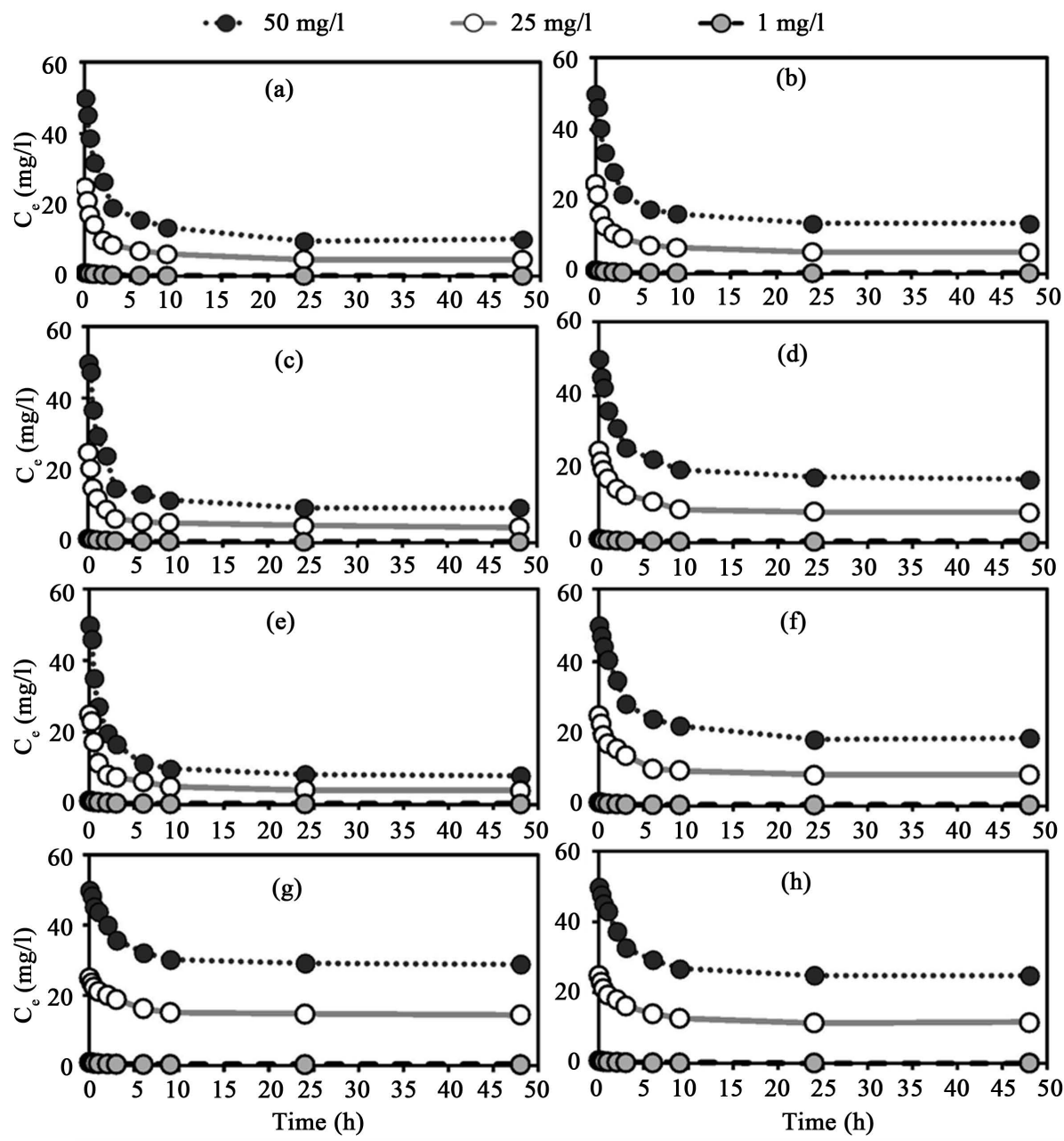

Figure 2. The adsorption equilibrium time of butachlor in eight soils. 


\subsection{Adsorption Equilibrium Study}

In this study, control samples showed no loss of pesticide. Thus, differences between the initial and equilibrium concentrations were assumed to be due to sorption onto soil. The concentration of pesticide adsorbed in the solid phase $q_{e}(\mathrm{mg} / \mathrm{kg})$, can be calculated as shown in Equation (1):

$$
q_{e}=\frac{V\left(C_{i}-C_{e}\right)}{m_{s}}
$$

where $V(L)$ is the final volume of solution in the suspension and $m_{s}(\mathrm{~g})$ is the mass of soil. In order to find the behavior of butachlor in different types of soils, adsorption isotherm studies were conducted at $27^{\circ} \mathrm{C} \pm 1{ }^{\circ} \mathrm{C}$ with an equilibrium time of $24 \mathrm{~h}$. The plots of $q_{e}$ versus $C_{e}$ for various initial concentrations in the range of $1-50$ $(\mathrm{mg} / \mathrm{l})$ are shown in Figure 3. It can be seen that sorption of butachlor by soils $\left(q_{e}\right)$ increased with solution equilibrium concentration $\left(C_{e}\right)$ suggesting that sorption sites were not saturated at the concentrations used in this study.

As the results could be fitted to straight line of correlation coefficients $r>0.98$, so the sorption data were fitted well into the linear model. Linear isotherms are often indicative of partitioning into the organic matter [12]. The linear isotherm has only one fitting parameter, $K_{d}$, and by definition, passes through origin. The applicability is to be judged via an appropriate regression through the origin. In our case, the linear fitting of data on all soils with $\mathrm{R}^{2}=0.97-0.99$, indicated a non-zero intercepts. Such behavior does not imply the inapplicability of the linear model as tested by the value of sum of squared errors, $S S E \%$, as given by Equation (2):

$$
S S E=\sqrt{\sum\left(K_{d, e x}-K_{d, c a l}\right)^{2} / N}
$$

where $N$ is the number of data points. The obtained values of SSE were 4.78, which imply that the variability of $K_{d}$ with $C_{e}$ is not significant. Most probably, errors in the values of $q_{e}$ at low $C_{e}$ values are the responsible for the non-zero intercepts [13].

The adsorption isotherm shape provides information concerning the adsorption mechanism. Most of the butachlor adsorption curves were of the L type, according to the classification proposed by Giles et al. [14], with a slope decreasing with increasing equilibrium concentration of the pesticide, which means that a decrease in sorption sites with increase concentration as the adsorptive sites become occupied, it is increasingly more difficult for sorbate molecules to find vacant sites. L type isotherms have been previously reported for butachlor adsorption [14] [15]. Moreover in some cases (soils (a), (c) and (e)) the butachlor adsorption curve was near-linear and hence of the $\mathrm{C}$ type.
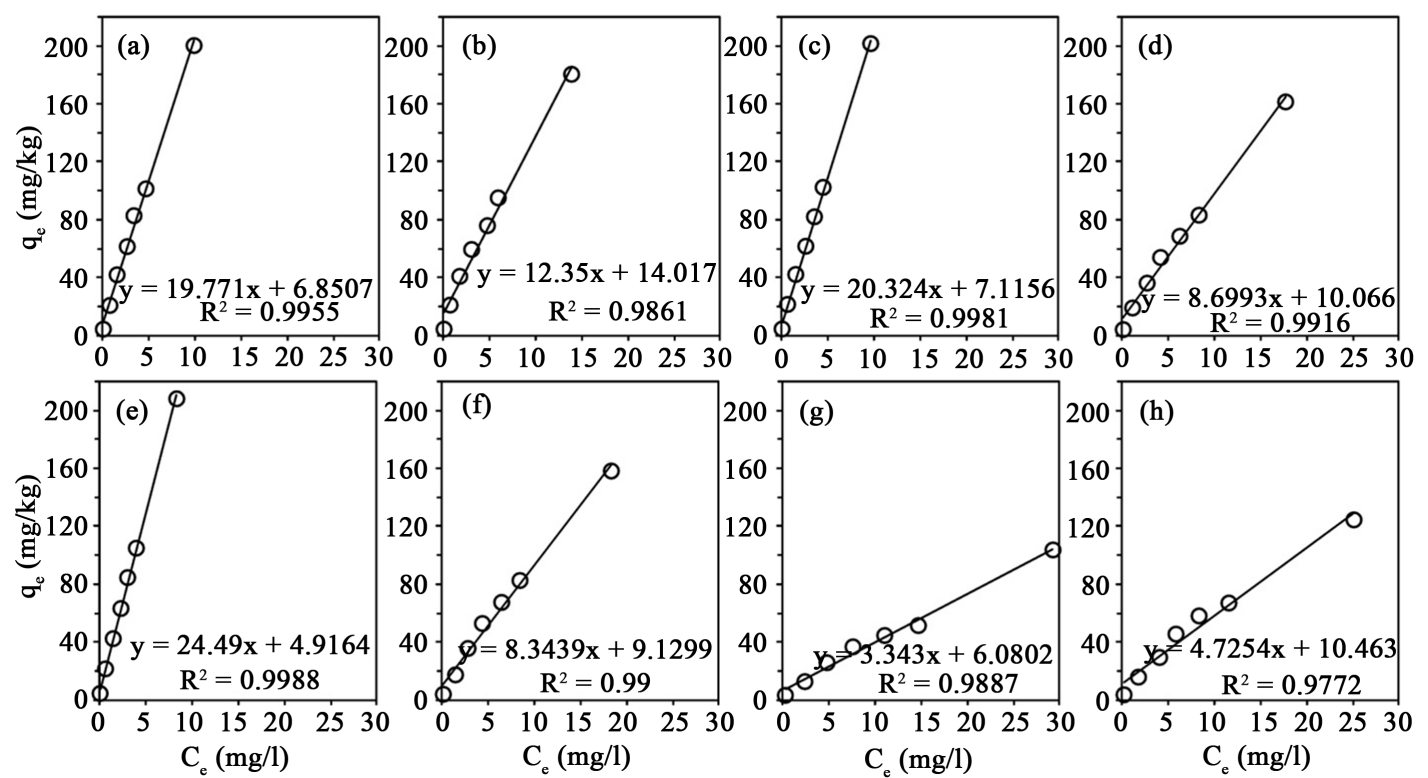

Figure 3. The adsorption curves of butachlor on eight soils. 
Pesticide soil/solution distribution coefficient, referred to as pesticide soil sorption value, is utilized to predict mobility of the pesticides and reflects its partitioning between adsorbing surfaces and the soil solution. Adsorption distribution coefficient $K_{d}(\mathrm{~L} / \mathrm{kg})$ was calculated for each pesticide-soil combination as Equation (3):

$$
K_{d}=\frac{q_{e}}{C_{e}}
$$

According to $K_{d}$ values it was possible to separate the soils into two groups as a function of their affinity towards butachlor: soils $E, C, A$ and $B$ had the strong sorption affinity to butachlor and exhibited the highest retention capacities $\left(20.35 \leq K_{d} \leq 29.07\right)$ while the other samples $D, F, H$ and $G$ had the weaker sorption affinity towards the butachlor and presented lower retention capacities $\left(5.05 \leq K_{d} \leq 13.05\right)$. The strongest sorption affinity of butachlor $\left(K_{d}=29.07\right)$ in soil $\mathrm{E}$ (a silty clay loam soil with highest organic matter) was about 5.8 -fold to the weakest sorption affinity $\left(K_{d}=5.05\right)$ of soil $G$ (a silt loam soil with lowest organic matter). This observation is in direct agreement with the general idea that adsorption of pesticides is higher on soils of higher organic matter. $K_{d}$ values of butachlor in our results is in accord with the reported data by Tatsuo et al. [16] in four Japan soils ranges from 14.8 to 38.9. In addition Chiang et al. [17] achieved findings in agreement with previous results by nine Taiwan soils at the range of 11.14 - 33.62. Likewise, Yu et al. [7] got similar results (range 6.78 - 17.36) on butachlor adsorption by five china soils.

As $O C$ is considered as the major component responsible for pesticide sorption, partition coefficient is often reported as normalized to the fraction of organic carbon $\left(f_{o c}\right)$ in the soil, represented as an organic carbon partition coefficient $\left(K_{O C}\right)$, which usually much less variable than $K_{d}$ for a given hydrophobic molecule and eliminates much of the variation in the $K_{d}$ values of the pesticide among different soils. The adsorption coefficient $\left(K_{d}\right)$ was calculated as a function of the organic carbon $(O C)$ and organic matter $(O M)$ of the soil with Equations (4) and (5) respectively:

$$
\begin{gathered}
K_{O C}=\frac{K_{d} \times 100}{\% O C} \\
K_{O M}=\frac{K_{d} \times 100}{\% O M}
\end{gathered}
$$

The values of $K_{O C}$ coefficient vary from 856 to $1109(\mathrm{~L} / \mathrm{kg})$ with mean $K_{O C}$ value of 980.24 . These values are in agreement with the literature (e.g. [8]) in the range of 729.2 - 1946 with a mean value of 1266 . The high $\mathrm{K}_{\mathrm{OC}}$ values suggest the contribution of mineral constituents as well as soil organic matter for pesticide sorption [18]. Liu et al. [8] found that $K_{O C}$ would be a poor predictive parameter for butachlor sorption on soils with $O C$ content higher than $4 \%$ and lower than $0.2 \%$. The determined organic matter partition coefficient $\left(K_{O M}\right)$ ranges from 495.18 to $643.61 \mathrm{~L} / \mathrm{kg}$. Adsorption results are presented in Table 3 .

Several general classifications of pesticide mobility in soil based on sorption $K_{O C}$ values have been proposed (which can be related to $K_{O M}, K_{d}$ and $K_{O W}$ ); one such example is given in Table 4 . This is primarily of use for non-ionized pesticides, because sorption of ionizable pesticides may depend on soil $\mathrm{pH}$, and shows that increas-

Table 3. Linear model adsorption and thermodynamic parameters of butachlor.

\begin{tabular}{ccccccc}
\hline Sample & $\mathrm{K}_{\mathrm{dcal}}$ & $\mathrm{K}_{\mathrm{dex}}$ & $\mathrm{K}_{\mathrm{OC}}$ & $\mathrm{K}_{\mathrm{OM}}$ & $\mathrm{r}$ & $\Delta \mathrm{G}^{\circ}$ \\
\hline A & 24.00 & 19.771 & 1042.63 & 604.57 & 0.998 & -7.927 \\
B & 20.35 & 12.350 & 1021.53 & 593.26 & 0.993 & -7.515 \\
C & 26.39 & 20.324 & 1109.20 & 643.61 & 0.999 & -8.163 \\
D & 13.05 & 8.699 & 952.53 & 552.95 & 0.996 & -6.407 \\
E & 29.07 & 24.490 & 1091.05 & 633.24 & 0.999 & -8.404 \\
F & 11.87 & 8.344 & 891.27 & 516.16 & 0.995 & -6.171 \\
G & 5.05 & 3.343 & 856.07 & 495.18 & 0.994 & -4.040 \\
H & 7.68 & 4.725 & 877.67 & 508.58 & 0.989 & -5.085 \\
\hline
\end{tabular}


Table 4. Classification of pesticide mobility in soil [24].

\begin{tabular}{ccccc}
\hline Mobility class & Log $\mathrm{K}_{\mathrm{OW}}$ & $\mathrm{K}_{\mathrm{OC}}(\mathrm{mL} / \mathrm{g})$ & $\mathrm{K}_{\mathrm{OM}}(\mathrm{mL} / \mathrm{g})$ & $\mathrm{K}_{\mathrm{d}}(\mathrm{mL} / \mathrm{g})^{\mathrm{a}}$ \\
\hline Nonmobile & $>5.3$ & $>4000$ & $>2320$ & $>46$ \\
Slightly mobile & $3.5-5.3$ & $500-4000$ & $290-2320$ & $5.8-46$ \\
Moderately mobile & $2.0-3.5$ & $75-500$ & $43-290$ & $0.86-5.8$ \\
Mobile & $0.6-2.0$ & $15-75$ & $9-43$ & $0.18-0.86$ \\
Very mobile & $<0.6$ & $<15$ & $<9$ & $<0.18$ \\
\hline
\end{tabular}

${ }^{\mathrm{a}} \mathrm{K}_{\mathrm{d}}$ values given for a soil with $2 \%$ organic matter.

ing lipophilicity decreases mobility [19]. On the basis of this classification, results showed butachlor in studied soils was slightly mobile. Low to moderate $K_{d}$ values suggest that this herbicide will predominantly partition out of the solution phase in which it is applied and adsorb moderately to soil particles, minimizing mobility in the soil solution and thus limiting exposure to sensitive species. This result is consistent with the previous finding reported by PPDB [9] which is considered transition state and slightly mobile with groundwater ubiquity score index (GUS $=2.02$ ) for this herbicide. It has a low risk of leaching to groundwater however, incidents of contamination have been recorded and it should be considered a potential water pollutant. With the beginning of the rain season in region, the pesticides from contaminated lands are washed off and leach to the water resources. Also during the flooding season, used butachlor in paddy fields can cause contamination into rivers by runoff. The concentration of this herbicide in special case reaches up to $324 \mathrm{ppb}$ in a well and $49.7 \mathrm{ppb}$ in Zilki Rood river in north of Iran [20]. It was also found that its concentration in the sturgeon fish hatchery has already been reported to be $0.67 \mathrm{ppb}$ in that region [21]. European regulations impose an environmental threshold of $0.1 \mathrm{ppb}$ active substance on pesticide concentrations in groundwater [22]. As the butachlor is dangerous to the aquatic ecosystem, so its mixing into natural waters should be avoided.

\subsection{Thermodynamic Study}

The change in the partial molar Gibbs free energy, $\Delta G^{\circ}\left(\mathrm{kJ} \cdot \mathrm{mol}^{-1}\right)$ as a result of adsorption process, was calculated from the thermodynamic Equation (6):

$$
\Delta G^{\circ}=-R T \ln K_{d}
$$

where $R$ is the universal gas constant $\left(8.314 \mathrm{~kJ} \cdot \mathrm{kmol}^{-1} \cdot \mathrm{K}^{-1}\right)$ and $\mathrm{T}$ is temperature in Kelvin $(K)$. The greater the absolute magnitude of $\Delta G^{\circ}$ value, the greater is the extent to which the adsorption reaction may take place. The $\Delta G^{\circ}$ values (Table 3 ) in all cases were negative and small. It means that the adsorption process was feasible, spontaneous and exothermic which an increase in temperature will result a decreased sorption and favors the desorption process. Moreover it has been reported that $\Delta G^{\circ}$ up to $-20 \mathrm{~kJ} \cdot \mathrm{mol}^{-1}$ is consistent with physical adsorption, while $\Delta G^{\circ}$ values more negative than $-40 \mathrm{~kJ} \cdot \mathrm{mol}^{-1}$ involve chemical adsorption [23]. The $\Delta G^{\circ}$ values in this study were $<-9 \mathrm{~kJ} \cdot \mathrm{mol}^{-1}$, which indicated that physical adsorption was the predominant mechanism in the sorption process. Thermodynamic parameter indicated favorable adsorption of butachlor on soils.

\subsection{Statistical Analysis}

In order to determine soil various properties involved in pesticide adsorption on the soils, a statistical analysis of correlations was performed through Pearson and Spearman tests. The obtained Pearson (P) and Spearman (S) correlation coefficients between $\mathrm{K}_{\mathrm{d}}$ and soil characteristics are reported in Table 5. Since the selected soils showed insignificant $\mathrm{pH}$ variation from 6.85 to 8.1 , hence the effect of $\mathrm{pH}$ on pesticides adsorption was ignored.

The analysis of these correlations showed that OC, CEC, Rt, TNV, RCO and clay were the effective soil characteristics for butachlor retention on studied soils. While $\mathrm{K}_{\mathrm{d}}$ was positively correlated to soil organic carbon content $(\mathrm{P}=0.997, \mathrm{~S}=0.998)$, it showed some negative correlation to TNV content $(\mathrm{P}=-0.809, \mathrm{~S}=-0.714)$. Pearson test showed that there was significant correlation with clay content $(p$-value $<0.05)$ while Spearman test showed that this correlation with clay was not significant ( $p$-value $>0.05)$. In fact, several studies underlined that clay mineral contribution to non-ionic pesticide sorption was not significant unless clay to organic carbon 
Table 5. Pearson (P) and Spearman (S) correlation coefficients between $\mathrm{K}_{\mathrm{d}}$ and soil characteristics.

\begin{tabular}{cccccccccc}
\hline & Sand & Silt & Clay & OC & RCO & EC & CEC & TNV & Rt \\
\hline P & -0.551 & -0.243 & $\mathbf{0 . 7 2 9}$ & $\mathbf{0 . 9 9 7}$ & $-\mathbf{0 . 8 5 6}$ & -0.548 & $\mathbf{0 . 9 6 3}$ & $\mathbf{- 0 . 8 0 9}$ & $\mathbf{- 0 . 9 5 1}$ \\
$p$-value & 0.157 & 0.562 & 0.04 & 0.001 & 0.007 & 0.159 & 0.001 & 0.015 & 0.001 \\
S & -0.494 & -0.286 & 0.618 & $\mathbf{0 . 9 9 8}$ & $-\mathbf{0 . 8 8 1}$ & -0.19 & $\mathbf{0 . 9 7 6}$ & $\mathbf{- 0 . 7 1 4}$ & $\mathbf{- 0 . 9 5 2}$ \\
$p$-value & 0.213 & 0.493 & 0.102 & 0.001 & 0.004 & 0.651 & 0.001 & 0.047 & 0.001 \\
\hline
\end{tabular}

Values in bold indicate that the correlation was significant at a $5 \%$ risk threshold, $p$-value $<0.05$.

ratio (RCO) was higher than 50 [25], or even 60 [8]. While RCO values in studied soils are between 12.61 and 27.12 .

Both tests indicated that there was a significant correlation between $K_{d}$ and $R_{t}(P=-0.951$ and $S=-0.952$, both with $p$-value $<0.01$ ). Thus, butachlor retention in the calcareous soils appeared notably governed by OC content and $\mathrm{R}_{\mathrm{t}}$ with an opposite effect. It was also found that, $\mathrm{RCO}$ and CEC are negatively $(\mathrm{P}=-0.856, \mathrm{~S}=$ $-0.881)$ and positively $(\mathrm{P}=0.963, \mathrm{~S}=0.976)$ correlated to $\mathrm{K}_{\mathrm{d}}$, respectively with $p$-value $<0.01$. The correlations calculated for sand, silt and EC were not significant for both Pearson and Spearman tests (the corresponding $p$-values were greater than 0.05 ).

\subsection{Effect of Organic Matter, Clay and TNV Content on Butachlor Sorption}

Results of this study demonstrated that organic carbon more affected the adsorption of butachlor on soils with higher OC. The sorption of butachlor on different soils was found to decrease in the order: $\mathrm{E}>\mathrm{C}>\mathrm{A}>\mathrm{B}>\mathrm{D}>$ $\mathrm{F}>\mathrm{H}>\mathrm{G}$ that this sequences follows the general trend for organic matter content in soils. No matter of type of organic matter, the sorption behavior of butachlor depends on the total organic matter content of the eight soils. Correlation study shows that soil organic matter content appears to control butachlor sorption $(\mathrm{r}=0.99 ; p<0.01)$. This observation is in agreement with that of most researchers who noted that adsorption was higher at high OC (e.g. [26]).

The soil samples C and D (clay loam soils) and also samples E and F (silty clay loam soils) with clear differences in organic matter content were selected to study role of organic matter on butachlor sorption in texturally similar soils. The OM content in the sample $\mathrm{C}$ and $\mathrm{D}$ was $4.1 \%$ and $2.36 \%$, respectively. The sorption coefficient $\left(\mathrm{K}_{\mathrm{d}}\right)$ of butachlor in sample $\mathrm{C}$ was two times higher than sample $\mathrm{D}$ with similar texture. OM content in sample $\mathrm{F}(2.3 \%)$ is much lower than sample $\mathrm{E}(4.59 \%)$ and therefore, sorption of butachlor in sample $\mathrm{E}$ is stronger. Thus, it is evident that apart from textural differences, increase in organic matter content intensified sorption of butachlor and decreased the mobility of it in soil. Although organic matter is the important factor in influencing the butachlor sorption on the soils (e.g. [7]), but it is affected by inorganic fraction, such as clay and amorphous sesquioxides. In fact, total organic carbon (TOC), clay, amorphous $\mathrm{Fe}_{2} \mathrm{O}_{3}$, silt content, $\mathrm{CEC}$, and $\mathrm{pH}$ had a combined effect on the butachlor sorption on soil [8].

The high $\mathrm{K}_{\mathrm{d}}$ value for soil E may be explained by presence of high clay $(36 \%)$ and organic matter $(4.59 \%)$ contents in this sample. The most clay content was observed in soil $\mathrm{E}$, however high amount of organic matter in this soil prevents to detect direct effect of clays on adsorption. As there is significant positive correlation between clay and organic carbon contents in studied soils, adsorption process can be attributed to both of parameters. The clay content of soils is a secondary critical parameter in pesticide adsorption, although its role is often masked by that of organic matter [27]. The soils with the ratio of clay content to TOC content (RCO) values are less than 60 , adsorbed butachlor mainly by the partition into soil organic matter matrix. The soils with RCO values are higher than 60 , adsorbed butachlor by the combination of the partitioning into soil organic matter matrix and adsorption on clay surface.

The above discussed results indicated that the organic matter in the soils was the dominant factor in pesticides adsorption process, which favors pesticide retention while on the other hand; carbonates reduces sorption capacities of soils [28]. In order to consider simultaneously the influences of these two soil components on pesticide sorption, Rt ratio as a new parameter suggested by El Arfaoui et al. [28], to take into account the inhibiting effect of calcite (here we used TNV as calcite present as major mineral for all samples) on OM retention and for the prediction of pesticides retention in calcareous soils. Studied soils can be divided into two groups: soils poor 
in carbonates (A, C and $\mathrm{E} ;<15 \%$ ) and soils moderately rich in carbonates $(\mathrm{B}, \mathrm{D}, \mathrm{F}, \mathrm{G}$ and $\mathrm{H}$; between $15 \%$ and $30 \%)$. Soils composed of less than $15 \% \mathrm{TNV}$ exhibited relatively high sorption capacity $\left(24 \leq \mathrm{K}_{\mathrm{d}} \leq 29.07 \mathrm{~L} / \mathrm{kg}\right)$. For these soils, higher OM content resulted in greater retention capacity. Conversely, for those samples contain TNV above $15 \%$, amounts of retained butachlor were reduced $\left(5.05 \leq \mathrm{K}_{\mathrm{d}} \leq 20.35 \mathrm{~L} / \mathrm{kg}\right)$. Sample G with highest Rt value had lowest adsorption coefficient, whereas, lowest Rt values were calculated for samples A, C, E which had high adsorption values for butachlor.

This finding is in accordance with several works reporting low affinities of calcareous soils towards pesticides [29]. It is well accepted that calcite is inert towards pesticides [30], but it might affect pesticide retention indirectly, by "coating" OM, thus making sorption sites less accessible to pollutants, and leading consequently to the low sorption capacities observed in calcareous soils [31]. Thus the proposed Rt ratio as a useful parameter in addition to OM can help to assess the mobilization potential of uncharged pesticides in calcareous soils and the risk of groundwater contamination [31].

\section{Conclusion}

Sorption coefficients were variable among soils and followed a general order similar to trend of organic matter content in soils. The value of the regression $(r>0.98)$ showed the applicability of the linear model. Also, the most of soils showed L-type isotherm, indicating that organic matter had a high affinity for butachlor. Organic matter and Rt were identified as the main two parameters governing butachlor retention in soils. The $\Delta \mathrm{G}^{\circ}$ values indicated spontaneous and exothermic adsorption process, and physical adsorption was the predominant mechanism in the sorption process. The low to moderate $\mathrm{K}_{\mathrm{d}}$ values represents intermediate adsorption behavior and slight mobility of butachlor in studied soils. In spite of low risk of leaching to groundwater, there is still possibility of water contamination during the occasional heavy rainfall by runoff events. If rainfall occurs immediately after pesticide, application can lead to rapid loss of pesticide from soil; relatively high proportion of pesticide may be available to leach, resulting in contamination of surface and groundwater. Results will be useful in developing improved pesticide management practices to reduce water contamination by pesticides.

\section{References}

[1] Autio, S., Siimes, K., Laitinen, P., Ramo, S., Oinonen, S. and Eronen, L. (2004) Adsorption of Sugar Beet Herbicides to Finnish Soils. Chemosphere, 55, 215-226. http://dx.doi.org/10.1016/j.chemosphere.2003.10.015

[2] Kibe, K., Takahashi, M., Kameya, T. and Urano, K. (2000) Adsorption Equilibriums of Principal Herbicides on Paddy Soils in Japan. Science of the Total Environment, 263, 115-125. http://dx.doi.org/10.1016/S0048-9697(00)00671-9

[3] Hernández, M., Villalobos, P., Morgante, V., González, M., Reiff, C., Moore, E. and Seeger, M. (2008) Isolation and Characterization of a Novel Simazine-Degrading Bacterium from Agricultural Soil of Central Chile, Pseudomonas sp. MHP41. FEMS Microbiology Letters, 286, 184-190. http://dx.doi.org/10.1111/j.1574-6968.2008.01274.x

[4] Ateeq, B., Farah, M.A. and Ahmad, W. (2006) Evidence of Apoptotic Effects of 2,4-D and Butachlor on Walking Catfish, Clarias batrachus, by Transmission Electron Microscopy and DNA Degradation Studies. Life Science, 78, 977986. http://dx.doi.org/10.1016/j.lfs.2005.06.008

[5] Geng, B.R., Yao, D. and Xue, Q.Q. (2005) Genotoxicity of the Pesticide Dichlorovos and Herbicide Butachlor in Rhacophorus Megacephal us tadpoles. Acta Zoologica Sinica (China), 51, 447-454.

[6] Xu, D.P., Xu, Z.H., Zhu, S.Q., Cao, Y.Z., Wang, Y., Du, X.M., Gu, Q.B. and Li, F.S. (2005) Adsorption Behavior of Herbicide Butachlor on Typical Soils in China and Humic Acids from the Soil Samples. Journal of Colloid and Interface Science, 285, 27-32. http://dx.doi.org/10.1016/j.jcis.2004.11.034

[7] Yu, Y.L., Wu, X.M., Li, S.N., Fang, H., Zhan, H.Y. and Yu, J.Q. (2006) An Exploration of the Relationship between Adsorption and Bioavailability of Pesticides in Soil to Earthworm. Environmental Pollution, 141, 428-433. http://dx.doi.org/10.1016/j.envpol.2005.08.058

[8] Liu, Z., He, Y., Huang, P. and Jilani, G. (2008) The Ratio of Clay Content to Total Organic Carbon Content Is a Useful Parameter to Predict Adsorption of the Herbicide Butachlor in Soils. Environmental Pollution, 152, 163-171. http://dx.doi.org/10.1016/j.envpol.2007.05.006

[9] PPDB (2012) Pesticide Properties Database (PPDB) Developed by the Agriculture and Environment Research Unit, University of Hertfordshire, UK.

[10] OECD (2000) OECD Guidelines for the Testing of Chemicals: Adsorption-Desorption Using a Batch Equilibrium Method. Organisation for Economic Co-operation and Development.

[11] Liu, Y.H., Xu, Z.Z., Wu, X.G., Gui, W.J. and Zhu, G.N. (2010) Adsorption and Desorption Behavior of Herbicide Di- 
uron on Various Chinese Cultivated Soils. Journal of Hazardous Materials, 178, 462-468.

http://dx.doi.org/10.1016/j.jhazmat.2010.01.105

[12] Chiou, C.T., Potter, P.E. and Schmedding, D.W. (1983) Partition Equilibriums of Nonionic Organic Compounds between Soil Organic Matter and Water. Environmental Science \& Technology, 17, 227-231. http://dx.doi.org/10.1021/es00110a009

[13] Elshafei, G.S., Nasr, I.N., Hassan, A.S.M. and Mohammad, S.G.M. (2009) Kinetics and Thermodynamics of Adsorption of Cadusafos on Soils. Journal of Hazardous Materials, 172, 1608-1616. http://dx.doi.org/10.1016/j.jhazmat.2009.08.034

[14] Giles, C.H., MacEwan, T.H., Nakhwa, S.N. and Smith, D. (1960) Studies in Adsorption: Part XI. A System of Classification of Solution Adsorption Isotherms and Its Use in Diagnosis of Adsorption Mechanisms and in Measurement of Specific Surface Area Solids. Journal of the Chemical Society, 14, 3973-3993. http://dx.doi.org/10.1039/jr9600003973

[15] Wang, Q.Q., Yang, W.C. and Liu, W.P. (1999) Adsorption of Acetanilide Herbicides on Soils and Its Correlation with Soil Properties. Pesticide Science, 55, 1103-1108.

Welhouse, G.J. and Bleam, W.F. (1992) NMR Spectroscopic Investigation of Hydrogen Bonding in Atrazine. Environmental Science \& Technology, 26, 959-964.

[16] Sato, T., Kohnosu, S. and Hartwig, J.F. (1987) Adsorption of Butachlor to Soils. Journal of Agricultural and Food Chemistry, 35, 397-402. http://dx.doi.org/10.1021/jf00075a028

[17] Chiang, H.C., Yen, J.H. and Wang, Y.S. (1997) Sorption of Herbicides Butachlor, Thiobencarb, and Chlomethoxyfen in Soils. Bulletin of Environmental Contamination and Toxicology, 58, 758-763. http://dx.doi.org/10.1007/s001289900398

[18] Flores, C., Morgante, V., González, M., Navia, R. and Seeger, M. (2009) Adsorption Studies of the Herbicide Simazine in Agricultural Soils of the Aconcagua Valley, Central Chile. Chemosphere, 74, 1544-1549. http://dx.doi.org/10.1016/j.chemosphere.2008.10.060

[19] Bromilow, R.H. (2005) Pesticides. In: Hillel, D., Rosenzweig, C., Powlson, D., Scow, K., Singer, M. and Sparks, D., Eds., Encyclopedia of Soils in the Environment, Vol. 3, Elsevier Ltd., Amsterdam, 188-195.

[20] Yousefi Falakdehi, O., Golparvar, Gh., Safdel, H. and Lasht Neshayi, A. (2012) Investigation of Water Pollution in Zilki Rood in Gilan Province. Iran Water Research Journal, 10, 6. (In Persian)

[21] Arshad, U., Aliakbar, A., Sadeghi, M., Jamalzad, F. and Chubian, F. (2006) Pesticide (Diazinon and Butachlor) Monitoring in Waters of the Shahid Beheshti Sturgeon Hatchery, Rasht, Iran. Journal of Applied Ichthyology, 22, 231-233. http://dx.doi.org/10.1111/j.1439-0426.2007.00957.x

[22] European Union (2000) Directive 2000/60/EC of the European Parliament and of the Council of 23 October 2000 Establishing a Framework for Community Action in the Field of Water Policy. Official Journal of the European Communities, 327, 1-72.

[23] Horsfall, M., Spiff, A.I. and Abia, A.A. (2004) Studies on the Influence of Mercaptoacetic Acid (MAA) Modification of Cassava (Manihot sculenta Cranz) Waste Biomass on the Adsorption of $\mathrm{Cu}^{2+}$ and $\mathrm{Cd}^{2+}$ from Aqueous Solution. Bulletin of the Korean Chemical Society, 25, 969-976. http://dx.doi.org/10.5012/bkcs.2004.25.7.969

[24] Hollis, J.M. (1991) Mapping the Vulnerability of Aquifers and Surface Waters to Pesticide Contamination at the National/Regional Scale. In: Walker, A., Ed., Pesticides in Soils and Water, BCPC Monograph, Vol. 47, National Soil Resources Institute, Cranfield University, Silsoe, 165-174.

[25] Spurlock, F. and Biggar, J.W. (1994) Thermodynamics of Organic Chemical Partition in Soils. 2. Nonlinear Partition of Substituted Phenylureas from Aqueous Solution. Environmental Science \& Technology, 28, 996-1002. http://dx.doi.org/10.1021/es00055a006

[26] Tang, Z.W., Zhang, W. and Chen, Y.M. (2009) Adsorption and Desorption Characteristics of Monosulfuron in Chinese Soils. Journal of Hazardous Materials, 166, 1351-1356. http://dx.doi.org/10.1016/j.jhazmat.2008.12.052

[27] Theng, B.K.G. (1974) The Chemistry of Clay-Organic Reactions. John Wiley and Sons, New York.

[28] El Arfaoui, A., Sayen, S., Marceau, E., Stievano, L., Guillon, E. and Couderchet, M. (2009) Relationship between Soil Composition and Retention Capacity of Terbumeton onto Chalky Soils. Environmental Chemistry, 6, 245-252. http://dx.doi.org/10.1071/EN08105

[29] Dubus, I.G., Barriuso, E. and Calvet, R. (2001) Sorption of Weak Organic Acids in Soils: Clofencet, 2,4-D and Salicylic Acid. Chemosphere, 45, 767-774. http://dx.doi.org/10.1016/S0045-6535(01)00108-4

[30] Kovaios, I.D., Paraskeva, C.A., Koutsoukos, P.G. and Payatakes, A.C. (2006) Adsorption of Atrazine on Soils: Model Study. Journal of Colloid and Interface Science, 299, 88-94. http://dx.doi.org/10.1016/j.jcis.2006.01.057

[31] El Arfaoui, A., Sayen, S., Paris, M., Keziou, A., Couderchet, M. and Guillon, E. (2012) Is Organic Matter Alone Sufficient to Predict Isoproturon Sorption in Calcareous Soils? Science of the Total Environment, 432, 251-256. http://dx.doi.org/10.1016/j.scitotenv.2012.05.066 